\title{
Sweet Syndrome in an Elderly Man With Well- Controlled Human Immunodeficiency Virus
}

\author{
Steven M. Mudroch 1, 2 , Craig Rohan 3, 2, 4, Nicholas G. Conger 5, 2, 4, David A. Lindholm 5, 2, 4 \\ 1. Department of Medicine, Wright-Patterson Medical Center, Wright-Patterson Air Force Base, USA 2. Department of \\ Medicine, Wright State University, Dayton, USA 3. Department of Dermatology, Wright-Patterson Medical Center, \\ Wright-Patterson Air Force Base, USA 4. Department of Medicine, Uniformed Services University of the Health \\ Sciences, Bethesda, USA 5. Department of Infectious Diseases, Wright-Patterson Medical Center, Wright-Patterson Air \\ Force Base, USA
}

Corresponding author: Steven M. Mudroch, steven.m.mudroch2.mil@mail.mil

\begin{abstract}
Acute febrile neutrophilic dermatosis, or Sweet syndrome, is a rare disorder associated with medications, underlying malignancy, or systemic inflammatory conditions. We present the case of a 71-year-old male living with well-controlled human immunodeficiency virus (HIV) on antiretroviral therapy, who presented with multiple painful, pseudo-vesicular, almost-necrotic appearing papules on his bilateral palms in the setting of constitutional symptoms and altered mental status. Biopsy of his palmar lesions revealed a dense, diffuse, dermal neutrophilic infiltrate consistent with Sweet syndrome. Infectious, rheumatologic, and oncologic work-up was negative. He was treated initially with intravenous immunoglobulin, prednisone, and dapsone; and he was continued on suppressive dapsone. He responded well clinically, but he relapsed multiple times in the setting of medication non-adherence before his ultimate diagnosis with sarcoidosis. A review of the literature of persons living with HIV and diagnosed with Sweet syndrome reveals no clear clinical association between the two despite plausible pathologic mechanisms. Patients living with HIV who are diagnosed with Sweet syndrome should be evaluated thoroughly for potential etiologies; the search for the underlying etiology of Sweet syndrome should go beyond their diagnosis of HIV.
\end{abstract}

Categories: Dermatology, Internal Medicine, Infectious Disease

Keywords: sweet syndrome, hiv, acute febrile neutrophilic dermatosis

\section{Introduction}

Dermatologic conditions are common in persons living with human immunodeficiency virus (HIV). Although certain dermatologic conditions are more likely with a greater degree of immunosuppression, new-onset skin lesions can remain a diagnostic challenge even in well-controlled HIV [1]. We present the case of an elderly male with well-controlled HIV who developed acute febrile neutrophilic dermatosis (Sweet syndrome) and review the literature for case reports of patients with HIV and Sweet syndrome.

Received 08/07/2020

Review began 08/13/2020 Review ended 09/01/2020 Published 09/09/2020

○ Copyright 2020 Mudroch et al. This is an open access article distributed under the terms of the Creative Commons Attribution License CC-BY 4.0., which permits unrestricted use, distribution, and reproduction in any medium, provided the original author and source are credited.

\section{Case Presentation}

A 71-year-old male with longstanding HIV, with a CD4 count of 320 cells $/ \mu \mathrm{L}$ and viral load of $0 \mathrm{c} / \mathrm{mL}$ on tenofovir disoproxil fumarate, emtricitabine, and dolutegravir, presented to the Infectious Disease clinic with constitutional symptoms, altered mental status, and multiple painful, pseudo-vesicular, almostnecrotic-appearing papules on his bilateral palms (Figure 1). The lesions arose in the preceding few days to weeks and were associated with subjective fevers and night sweats. Recent medical history included completion of treatment for pulmonary histoplasmosis eight months prior, a transition from rilpivirine to dolutegravir as his antiretroviral anchor drug approximately one month prior, progressive confusion over several weeks, ongoing evaluation for failure to thrive, and treatment with azithromycin for an unknown infection five days prior at an outside facility. He was admitted to the hospital for further evaluation. Diagnostic work-up was notable for an elevated erythrocyte sedimentation rate (ESR) of 109 $\mathrm{mm} / \mathrm{hr}$. Evaluation for infectious etiologies included four sets of negative blood cultures and a negative rapid plasma reagin, hepatitis B virus DNA, hepatitis C virus antibody, Histoplasma urine antigen, and transthoracic echocardiogram. Cerebrospinal fluid (CSF) analysis revealed normal chemistries, no pleocytosis, and negative Venereal Disease Research Laboratory assay, cryptococcal antigen, and bacterial culture. Testing for Neisseria gonorrhoeae was not performed at the time of his evaluation. Rheumatologic evaluation included no evidence of C3 or C4 deficiency, cryoglobulins, antinuclear antibody, antineutrophil cytoplasmic antibody, or rheumatoid factor. Oncologic work-up included an unrevealing peripheral blood smear, serum paraneoplastic antibody panel, serum protein electrophoresis, and fecal occult blood testing. There were no masses on computed tomography of the head, chest, abdomen, or pelvis. Magnetic resonance imaging (MRI) of the abdomen revealed splenic enlargement without focal lesion and no evidence of underlying malignancy. MRI of the brain revealed no evidence of acute vasculitis. 


\section{Cureus}
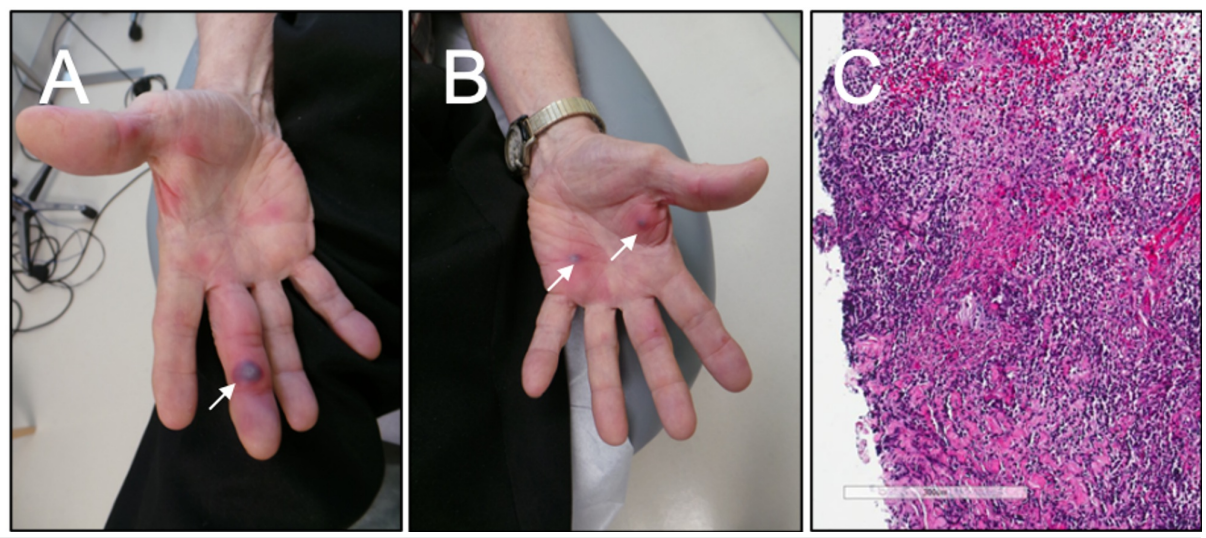

FIGURE 1: Initial clinical presentation and biopsy results.

(A) Right and (B) left palms demonstrating scattered painful, pseudo-vesicular, almost-necrotic-appearing papules on his bilateral palms [arrows]. (C) Dense, diffuse, dermal neutrophilic infiltrate on biopsy from one of his palmar lesions. No features of vasculitis were identified.

A biopsy of the palmar lesions demonstrated a dense, diffuse, dermal neutrophilic infiltrate and papillary dermal edema (Figure 1). The biopsy was not consistent with vasculitis. The Gram stain was negative, and bacterial and fungal cultures exhibited no growth. Neuro-Sweet disease was considered given his altered mentation and cutaneous findings in the absence of another infectious, inflammatory, or malignant etiology. Initial treatment for his Sweet syndrome included intravenous immunoglobulin (IVIG), dapsone (started at $50 \mathrm{mg}$ daily and titrated up to $100 \mathrm{mg}$ daily), and prednisone (up to $60 \mathrm{mg}$ daily). He demonstrated marked improvement in his skin lesions (Figure 2) and mental status by the time of hospital discharge eight days later. Prednisone was tapered off within two months, and his dapsone dose was tapered but continued as a suppressive, steroid-sparing therapy.

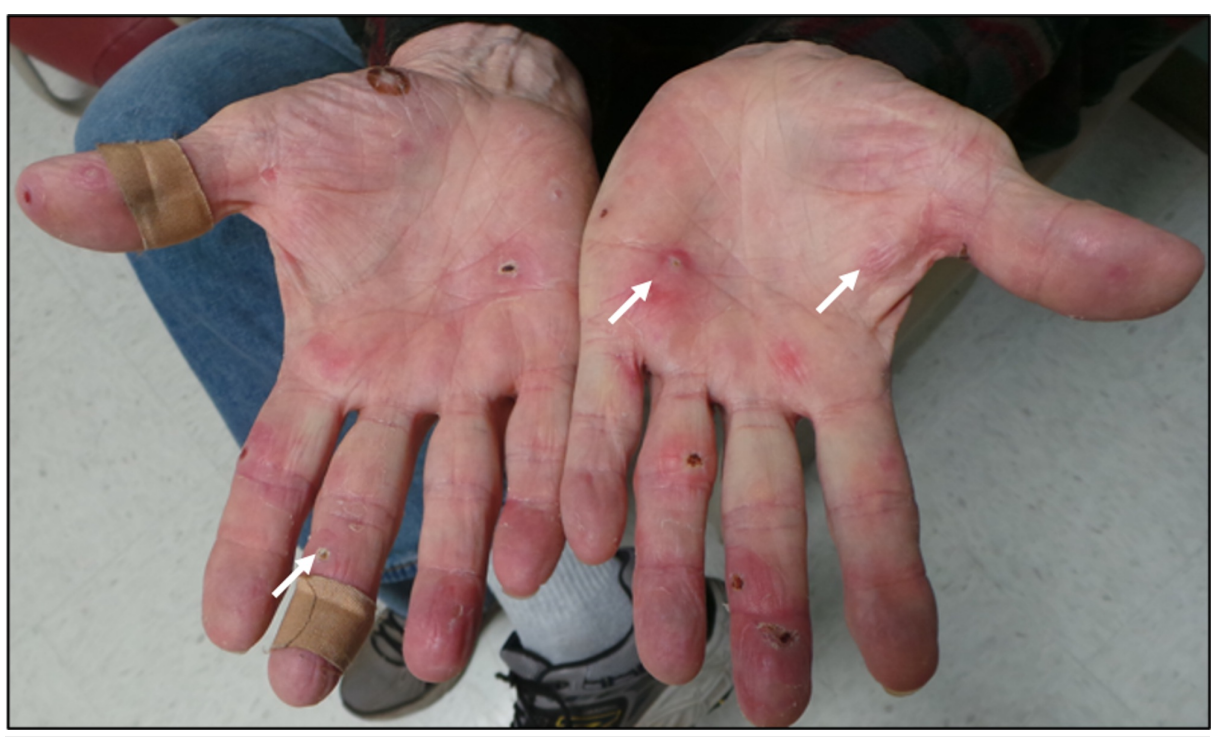

FIGURE 2: Follow-up clinical presentation.

Interval improvement of initial palmar lesions [arrows] four weeks after initiation of treatment with IVIG, prednisone, and dapsone.

IVIG: intravenous immunoglobulin.

He did not have a recurrence of his cutaneous findings until a period of dapsone non-adherence four months after his initial diagnosis. Dapsone and prednisone were restarted and re-tapered. Over the following six months, he continued to have recurrent flares of Sweet syndrome, thought to be secondary to medication non-adherence. Throughout this time, his viral load remained suppressed, and his CD4 count remained stable on an integrase-inhibitor-based regimen. 
Our patient was unable to be weaned off suppressive dapsone, prompting consideration for an unresolved, underlying etiology. Newly enlarged inguinal lymph nodes were found on palpation one year after the diagnosis of Sweet syndrome. Positron emission tomography (PET) demonstrated mild 18F-

fluorodeoxyglucose (FDG) avidity in his enlarged spleen, inguinal and retroperitoneal lymph nodes, and skeleton, but an excisional lymph node biopsy did not find evidence of lymphoma. Colonoscopy was also negative.

With the recurrence of bilateral palmar lesions almost two years after the initial presentation, a repeat punch biopsy was performed, revealing non-necrotizing granulomatous inflammation and leading to a diagnosis of sarcoidosis. He ultimately died 2.5 years after his initial presentation, with an unknown cause of death.

\section{Discussion}

Sweet syndrome is defined by major and minor criteria. The major criteria include acute, tender, erythematous, or violaceous plaques or nodules as well as neutrophilic dermal infiltrate in the absence of leukocytoclastic vasculitis. The minor criteria include antecedent fever or infection; concomitant fever, arthralgia, conjunctivitis, or malignancy; leukocytosis; good clinical response to systemic corticosteroids rather than antibiotics; and increased ESR [2]. Our patient met the case definition of Sweet syndrome based on both major criteria and three minor criteria (antecedent fever, good clinical response to steroids, and increased ESR). Classically, Sweet syndrome is more common in women in the fourth to sixth decades of life [1]; our patient is the oldest of the reported cases of Sweet syndrome in an individual living with HIV.

The Sweet syndrome has been described aptly as a "diagnosis searching for a cause," as the diagnosis should prompt evaluation for an underlying etiology [1]. Potential etiologies include infections, malignancy, autoimmune/inflammatory conditions, medications, and pregnancy; Sweet syndrome has also been described as classic or idiopathic if it is neither malignancy-associated nor drug-induced [1,2].

We performed a literature search using PubMed with search terms "HIV AND Sweet" or "HIV AND Acute febrile neutrophilic dermatosis," and identified 17 other published cases from 1994 to 2020 of Sweet syndrome in patients with HIV infection (Table 1). One of these cases is mentioned in the context of a larger study on histopathological findings, but no further supporting details were available for tabulation [3].

\begin{tabular}{|c|c|c|c|c|c|c|c|c|}
\hline Author [ref] & Year & $\begin{array}{l}\text { Age } \\
\text { (year) }\end{array}$ & Sex & $\begin{array}{l}\text { CD4 } \\
\text { (cells/ } \\
\mu L)\end{array}$ & $\begin{array}{l}\text { VL } \\
\text { (c/mL) }\end{array}$ & Etiology & $\begin{array}{l}\text { ART at } \\
\text { Sweet } \\
\text { onset }\end{array}$ & Treatment \\
\hline $\begin{array}{l}\text { Hilliquin et al. } \\
\text { [4] }\end{array}$ & 1992 & 30 & $\mathbf{F}$ & 283 & NR & HIV & None & $\begin{array}{l}\text { Prednisone } 30 \text { mg/day; colchicine } 1 \\
\text { mg/day }\end{array}$ \\
\hline $\begin{array}{l}\text { Berger et al. } \\
{[5]}\end{array}$ & 1994 & 43 & M & $<50$ & NR & $\begin{array}{l}\text { G-CSF, Kaposi } \\
\text { sarcoma }\end{array}$ & None & $\begin{array}{l}\text { Prednisone } 40 \text { mg/day; potassium } \\
\text { iodide solution; hydroxychloroquine } 200 \\
\text { mg BID }\end{array}$ \\
\hline $\begin{array}{l}\text { Berger et al. } \\
\text { [5] }\end{array}$ & 1994 & 54 & M & 143 & NR & Unknown & None & $\begin{array}{l}\text { Potassium iodide solution; stop NSAID } \\
\text { and glyburide }\end{array}$ \\
\hline $\begin{array}{l}\text { Bevilacqua et } \\
\text { al. [6] }\end{array}$ & 1999 & 41 & $\mathrm{~F}$ & 187 & 550,000 & $\begin{array}{l}\text { IRIS (possible), } \\
\text { Pneumocystis } \\
\text { pneumonia }\end{array}$ & $\begin{array}{l}\text { AZT, } \\
\text { DDC, } \\
\text { SQV }\end{array}$ & Prednisone 1 mg/kg \\
\hline Brady et al. [7] & 1999 & $\begin{array}{l}3 \\
\text { months }\end{array}$ & M & 368 & NR & HIV (new diagnosis) & None & $\begin{array}{l}\text { Polysporin ointment, topical; viscous } \\
\text { lidocaine, topical }\end{array}$ \\
\hline $\begin{array}{l}\text { Del Giudice et } \\
\text { al. [8] }\end{array}$ & 2004 & 47 & $\mathrm{~F}$ & 173 & 140,000 & ABC & $\begin{array}{l}3 T C \\
\text { NFV, } \\
\text { ABC }\end{array}$ & Stop ABC \\
\hline Tan et al. [9] & 2006 & 46 & M & 414 & NR & $\begin{array}{l}\text { Influenza } \\
\text { vaccination }\end{array}$ & None & Prednisolone 1 mg/kg/day \\
\hline $\begin{array}{l}\text { Inamadar and } \\
\text { Anitha [10] }\end{array}$ & 2008 & 30 & $\mathrm{~F}$ & 450 & NR & HIV & None & $\begin{array}{l}\text { Dapsone } 100 \text { mg/day; prednisone } 1 \\
\text { mg/kg/day }\end{array}$ \\
\hline $\begin{array}{l}\text { Cabanillas et } \\
\text { al. [11] }\end{array}$ & 2008 & 35 & M & 285 & 100,000 & HIV (new diagnosis) & None & Prednisone 50 mg/day \\
\hline Johnson et al. & 2008 & 37 & M & 530 & UD & Syphilis & $\begin{array}{l}\text { FTC, } \\
\text { TDF, }\end{array}$ & Corticosteroids; treat syphilis \\
\hline
\end{tabular}




\section{Cureus}

\begin{tabular}{|c|c|c|c|c|c|c|c|c|}
\hline \multicolumn{7}{|l|}{ [12] } & \multicolumn{2}{|l|}{$\begin{array}{l}\text { ATV, } \\
\text { RTV }\end{array}$} \\
\hline $\begin{array}{l}\text { Haddow } \\
\text { and Lehloenya } \\
\text { [13] }\end{array}$ & 2011 & 36 & $\mathrm{~F}$ & 217 & 21,000 & IRIS & $\begin{array}{l}\text { D4T, } \\
\text { 3TC, } \\
\text { LPV, } \\
\text { RTV }\end{array}$ & NR \\
\hline $\begin{array}{l}\text { Haddow and } \\
\text { Lehloenya [13] }\end{array}$ & 2011 & 51 & $\mathrm{~F}$ & 126 & 5,000 & IRIS & $\begin{array}{l}\text { D4T, } \\
\text { 3TC, EFV }\end{array}$ & Topical steroids; indomethacin \\
\hline $\begin{array}{l}\text { Deasy et al. } \\
{[14]}\end{array}$ & 2012 & 44 & M & 459 & 96,200 & $\begin{array}{l}\text { Bone marrow } \\
\text { dyscrasia }\end{array}$ & $\begin{array}{l}\text { ABC, } \\
\text { 3TC, EFV }\end{array}$ & $\begin{array}{l}\text { Colchicine } 500 \mathrm{mcg} \text { TID (dapsone and } \\
\text { prednisone ineffective) }\end{array}$ \\
\hline $\begin{array}{l}\text { Corral et al. } \\
{[15]}\end{array}$ & 2014 & 38 & $\mathrm{~F}$ & 620 & 28,000 & HIV & 3TC, EFV & Betamethasone \\
\hline $\begin{array}{l}\text { Rajendran et } \\
\text { al. [16] }\end{array}$ & 2014 & 67 & $\mathrm{~F}$ & 163 & NR & Unknown & None & Prednisone 1 mg/kg/day \\
\hline $\begin{array}{l}\text { Dong et al. } \\
\text { [17] }\end{array}$ & 2020 & 47 & $\mathrm{~F}$ & 70 & NR & IRIS & $\begin{array}{l}\text { 3TC, } \\
\text { TDF, } \\
\text { DTG }\end{array}$ & Thalidomide 100 mg/day \\
\hline Current case & 2020 & 71 & M & 320 & UD & Unknown & $\begin{array}{l}\text { TDF, } \\
\text { FTC, } \\
\text { DTG }\end{array}$ & $\begin{array}{l}\text { Prednisone } 60 \text { mg/day; IVIG; dapsone } \\
100 \text { mg/day }\end{array}$ \\
\hline
\end{tabular}

\section{TABLE 1: Cases of Sweet syndrome in persons living with HIV, arranged by the year of publication}

3TC: lamivudine, ABC: abacavir, ART: antiretroviral therapy, ATV: atazanavir, AZT: zidovudine, BID: twice daily, D4T: stavudine, DDC: zalcitabine, DTG: dolutegravir, EFV: efavirenz, F: female, FTC: emtricitabine, HIV: human immunodeficiency virus, IRIS: immune reconstitution inflammatory syndrome, IVIG: intravenous immunoglobulin, LPV: lopinavir, M: male, NFV: nelfinavir, NR: not reported, NSAID: non-steroidal anti-inflammatory drug, RTV: ritonavir, SQV: saquinavir, TID: three times daily, TDF: tenofovir, UD: undetectable, VL: viral load.

A review of the published cases highlights important unique proposed etiologies for Sweet syndrome in those living with HIV: immune reconstitution inflammatory syndrome (IRIS) in $25 \%$ of cases $[6,13,17]$, AIDS-defining conditions (i.e., Kaposi sarcoma and pneumocystis pneumonia) in two cases [5,6], and abacavir therapy in one case [8]. Other notable attributions include syphilis [12], influenza vaccination [9], bone marrow dyscrasia [14], and treatment with G-CSF [5]. No cause was determined in two of the cases.

The published cases do not indicate a clear association between Sweet syndrome and CD4 cell count (range: $<50$ to 530 cells/ $\mu \mathrm{L}$ ), the degree of viral suppression (range: undetectable to $550,000 \mathrm{c} / \mathrm{mL}$ ), or HIV itself. At least two reported cases have identified Sweet syndrome as a presenting manifestation of HIV infection $[7,11]$, and others postulate an association with HIV after other etiologies have been ruled out $[4,10,15]$. No definitive pathogenic mechanism has been elucidated to connect the two, though some hypothesize that HIV creates an environment more favorable to the pathogenesis of Sweet syndrome [6] through a hypersensitivity response with neutrophil chemotaxis [7,13], altered Type 1 and Type 2 helper T-cell response [14,17], and the presence of HIV trans-activating proteins [11]. Despite one-third of reported cases directly attributing HIV itself as the etiology of Sweet syndrome, larger studies involving nearly 1700 persons living with HIV and reporting to dermatology clinics have not identified Sweet syndrome as a presenting skin disorder $[18,19]$.

The underlying etiology of our patient's Sweet syndrome remains unknown. His recent transition to a dolutegravir-based regimen is notable given that one other case also reported initiation of a dolutegravirbased regimen [17], though that case was attributed ultimately to IRIS, and our patient had longstanding control of HIV. Sarcoidosis may have contributed, as it has been identified previously as a possible associated condition [20]. Although he had evidence of a systemic inflammatory condition at the time of his original presentation, the contribution of sarcoidosis is questionable, as there was no evidence of granuloma formation on biopsy at that time.

There was significant heterogeneity in treatment approaches for Sweet syndrome in those living with HIV, though a majority of treatments involved systemic anti-inflammatory and/or immunosuppressive therapies [4-7,9-11,13-16,20]. Duration of treatment was also variable, but successful treatments ranged from as little as ten days with a course of saturated potassium iodide solution [7], to two months of prednisone [4], often 


\section{Conclusions}

Sweet syndrome is classically associated with medications, malignancy, or systemic inflammatory conditions. It is unclear whether HIV is a true precipitating factor. Review of the literature has noted attributions of Sweet syndrome to IRIS, AIDS-defining conditions, medications, vaccinations, other infections, and altered bone marrow function. Our report demonstrates that Sweet syndrome should be part of the differential diagnosis in persons living with HIV who present with new skin plaques or nodules and constitutional symptoms, regardless of the patient's age and degree of HIV control. The search for the underlying etiology of Sweet syndrome in patients living with HIV should go beyond their diagnosis of HIV.

\section{Additional Information \\ Disclosures}

Human subjects: Consent was obtained by all participants in this study. Conflicts of interest: In compliance with the ICMJE uniform disclosure form, all authors declare the following: Payment/services info: All authors have declared that no financial support was received from any organization for the submitted work. Financial relationships: All authors have declared that they have no financial relationships at present or within the previous three years with any organizations that might have an interest in the submitted work. Other relationships: Copyright statement: Some authors are employees of the U.S. Government. This work was prepared as part of their official duties. Title 17 U.S.C. 105 provides that 'Copyright protection under this title is not available for any work of the United States Government.' Title 17 U.S.C. 101 defines a United States Government work as a work prepared by a military service member or employee of the United States Government as part of that person's official duties. Disclaimer: The contents of this publication are the sole responsibility of the author(s) and do not necessarily reflect the views, opinions, or policies of Uniformed Services University of the Health Sciences (USUHS), the Department of Defense (DoD), the Departments of the Air Force, or Wright-Patterson Medical Center. Mention of trade names, commercial products, or organizations does not imply endorsement by the U.S. Government. .

\section{Acknowledgements}

The authors thank the librarians of the Miami Valley Hospital Medical Library (Dayton, USA) for their assistance with the literature search.

\section{References}

1. Duke WH, Pantanowitz L: Editorial comment: Sweet syndrome - a diagnosis seeking a cause . AIDS Read. 2008, 18:136-138.

2. Rochet NM, Chavan RN, Cappel MA, Wada DA, Gibson LE: Sweet syndrome: clinical presentation, associations, and response to treatment in 77 patients. J Am Acad Dermatol. 2013, 69:557-564. 10.1016/j.jaad.2013.06.023

3. Rochael MC, Pantaleão L, Vilar EA, Zacaron LH, Spada EQ, Xavier MH, Rodrigues KS: Sweet's syndrome: study of 73 cases, emphasizing histopathological findings. An Bras Dermatol. 2011, 86:702-707. 10.1590/s0365-05962011000400012

4. Hilliquin P, Marre JP, Cormier C, Renoux M, Menkes CJ, Puissant A: Sweet's syndrome and monarthritis in a human immunodeficiency virus-positive patient. Arthritis Rheum. 1992, 35:484-486. 10.1002/art.1780350423

5. Berger TG, Dhar A, McCalmont TH: Neutrophilic dermatoses in HIV infection. J Am Acad Dermatol. 1994, 31:1045-1047. 10.1016/s0190-9622(09)80079-0

6. Bevilacqua S, Hermans P, Van Laethem Y, Demaubeuge J, Clumeck N: Sweet's syndrome in an HIV-infected patient. AIDS. 1999, 13:729-729. 10.1097/00002030-199904160-00015

7. Brady RC, Morris J, Connelly BL, Boiko S: Sweet's syndrome as an initial manifestation of pediatric human immunodeficiency virus infection. Pediatrics. 1999, 104:1142-1144. 10.1542/peds.104.5.1142

8. Del Giudice P, Vandenbos F, Perrin C, Bernard E, Marq L, Dellamonica P: Sweet's syndrome following abacavir therapy. J Am Acad Dermatol. 2004, 51:474-475. 10.1016/i.jaad.2003.09.033

9. Tan AW, Tan HH, Lim PL: Bullous Sweet's syndrome following influenza vaccination in a HIV-infected patient. Int J Dermatol. 2006, 45:1254-1255. 10.1111/j.1365-4632.2006.03005.x

10. Inamadar AC, Anitha B: HIV-seropositive patient with Sweet's syndrome and nodular scleritis, showing dramatic response after adding dapsone to systemic corticosteroid therapy. Int J Dermatol. 2008, 47:836838. 10.1111/j.1365-4632.2008.03648.x

11. Cabanillas M, Rodríguez-Blanco I, Sánchez-Aguilar D, Toribio J: Síndrome de Sweet: primera manifestación de infección por el virus de la inmunodeficiencia humana?. Actas Dermosifiliogr. 2008, 99:83-84. 10.1016/S0001-7310(08)74626-X

12. Johnson LE, Armstrong AW, Dezube BJ, Tahan SR, Gold HS: Images in HIV/AIDS: Sweet syndrome and syphilis in an HIV-infected person. AIDS Read. 2008, 18:134-135.

13. Haddow LJ, Lehloenya R, Mosam A, Malaka S, Moosa MY: Sweet syndrome: adverse drug reaction or novel manifestation of HIV-associated immune reconstitution inflammatory syndrome?. J Am Acad Dermatol. 2011, 65:23-25. 10.1016/j.jaad.2010.11.052

14. Deasy AM, Walker B, Layton AM, Lacey CJ: Sweet's syndrome in a patient with haemophilia, HIV and hepatitis C infection. Int J STD AIDS. 2012, 23:11-13. 10.1258/ijsa.2009.009314 


\section{Cureus}

15. Corral M, Arana E, Recarte M, Marcia A, Fritschy M: Sindrome de Sweet en paciente VIH positivo . Arch Argent Dermatol. 2014, 64:66-71.

16. Rajendran A, Zacharia GS, Zacharia SA, George KC: Sweet's syndrome in human immune deficiency virusinfected patient. Indian J Sex Transm Dis AIDS. 2014, 35:149-151. 10.4103/0253-7184.142413

17. Dong RJ, Huang SZ, Upadhyay P, Shrestha S, Zhai YJ, Li YY: Thalidomide in the treatment of Sweet's syndrome and eosinophilic folliculitis associated with immune reconstitution inflammatory syndrome. Front Med (Lausanne). 2020, 6:343. 10.3389/fmed.2019.00343

18. Goldstein B, Berman B, Sukenik E, Frankel SJ: Correlation of skin disorders with CD4 lymphocyte counts in patients with HIV/AIDS. J Am Acad Dermatol. 1997, 36:262-264. 10.1016/s0190-9622(97)70295-0

19. Muñoz-Pérez MA, Rodriguez-Pichardo A, Camacho F, Colmenero MA: Dermatological findings correlated with CD4 lymphocyte counts in a prospective 3 year study of 1161 patients with human immunodeficiency virus disease predominantly acquired through intravenous drug abuse. Br J Dermatol. 1998, 139:33-39. 10.1046/j.1365-2133.1998.02310.x

20. Dadban A, Hirschi S, Sanchez M, Lagrange B: Association of Sweet's syndrome and acute sarcoidosis: report of a case and review of the literature. Clin Exp Dermatol. 2009, 34:189-191. 10.1111/j.13652230.2008.02813.x 